\title{
Kebijakan Keamanan Pangan India Melawan Rezim Globalisasi
}

\author{
Ica Wulansari \\ Jurusan Hubungan Internasional, Universitas Al Azhar Indonesia
}

\begin{abstract}
ABSTRAK
Rezim internasional terbentuk oleh organisasi internasional di bawah Washington Consensus. Organisasi internasional seperti World Trade Organization (WTO) mengakomodasi kepentingan negara-negara maju. WTO membuat aturan main perdagangan dunia, salah satu di antaranya adalah mengatur subsidi pangan. Hal tersebut menimbulkan perdebatan mengenai besaran subsidi pangan antara negara maju dan negara berkembang. Dalam Pertemuan WTO di Bali, India memberikan usulan besaran subsidi pangan 5 persen lebih tinggi dibandingkan usulan WTO dan berhasil disetujui dalam forum WTO yang melahirkan Paket Bali. Usulan India mengenai besaran subsidi pangan terkait dengan kebijakan dalam negeri mengenai keamanan pangan. India pada September 2013 mengesahkan Undang-Undang Keamanan Pangan dan menerapkan kebijakan pangan murah untuk kaum miskin. Populasi yang besar menyebabkan India sangat rawan akan ancaman ketersediaan pangan. Penelitian ini menganalisis bagaimana kebijakan pangan India dalam memperkuat kepentingan nasionalnya di tengah rezim globalisasi.
\end{abstract}

Kata-kata Kunci: Globalisasi, WTO, Keamanan Pangan, India

International regimes are established by international organizations under the Washington Consensus. Thus International organizations such as WTO (World Trade Organizations) which accommodates developed countries interest. WTO has made world trade rule which set of food subsidy which stimulates a tough debate between developed countries and developing countries. In the WTO meeting, India proposed food subsidy for 5 percent higher that it is suggested by WTO and successfully approved in the WTO Forum known as Bali Package. India's proposal regarding food security is part of India `s domestic policies. In September 2013, India passed The Indian National Food Security Act and applied cheap food for the poor. Dense population in India reates insecurity, especially on food accessibility. This research is conducted to explain the policy of the Indian government in strengthening its national interest amid the globalization.

Keywords: Globalization, WTO, Food Security, India. 
Dalam pertemuan WTO (World Trade Organization) di Bali pada Desember 2013 tercapai kesepakatan yang disebut dengan Paket Bali yang dihadiri 159 negara anggota WTO. Paket Bali dicapai melalui kesepakatan antara anggota WTO yang berupaya mengurangi hambatan birokrasi dalam alur distribusi dan perdagangan global. Namun, sebelum tercapai kesepakatan Paket Bali, ketika berupa draft terjadi penolakan dari perwakilan pemerintah India. Menteri Perdagangan India, Anand Sharma melakukan upaya walk out karena menolak ketentuan mengenai subsidi pangan. India dengan tegas menolak kompromi yang diajukan negara-negara maju mengenai besaran subsidi hingga 15 persen dengan ketentuan waktu berlaku selama 4 tahun. India memberikan usulan meningkatkan cadangan pangan dari 10 persen menjadi 15 persen dari total produksi pangan dengan waktu subsidi yang tidak terbatas (Indopos 2013).

Sikap tegas India memiliki keterkaitan dengan strategi ketahanan pangan India yang telah ditetapkan dalam The Indian National Food Security Act yang telah disahkan pada 10 September 2013. Dalam pembukaan yang tercantum dalam The Indian National Food Security Act No 20 of 2013 bahwa Undang-Undang ini menegaskan negara harus menyediakan pangan dan nutrisi dalam setiap tahap kehidupan warganya, dengan memastikan ketersediaan dengan kuantitas yang cukup maupun kualitas yang baik dengan harga yang terjangkau bagi semua warga negara. Maka dengan keberadaan regulasi ini memastikan kebutuhan dasar pangan (untuk komoditas biji-bijian meliputi beras dan gandum) untuk warga India dengan populasi yang cukup besar agar memiliki kemudahan dalam menjangkau pangan dan keterjangkauan dalam harga. Selain itu, regulasi ini mengharuskan subsidi pangan untuk menunjang keterjangkauan warga akan pangan. India cukup sadar bahwa globalisasi dengan perdagangan bebas dapat menimbulkan dampak negatif salah satunya terhadap fluktuasi kenaikan harga pangan maupun ancaman kelangkaan pangan. Perdagangan bebas mendorong perusahaan multinasional untuk membuka perusahaan pangan yang dapat menggusur lahan warga miskin.

Anand Sharma dalam pertemuan WTO menolak ketentuan yang dapat membahayakan subsidi untuk biji-bijian berdasarkan kebijakan India yang dapat memberikan pangan dengan harga terjangkau bagi kaum miskin. India berperan penting dalam kesepakatan WTO karena menjadi pelopor sikap tegas yang mewakili negara berkembang. Setelah India melakukan tindakan yang tegas, diikuti dengan Kuba, Bolivia, Nikaragua dan Venezuela yang menolak draf kesepakatan WTO. Pada masa Putaran WTO di Uruguay pun negosiasi terkait subsidi pertanian menjadi hal yang alot untuk mencapai kesepakatan (Antara 2013). 
Dalam era globalisasi ekonomi, pengaturan terkait perdagangan menjadi monopoli bagi negara-negara maju melalui forum pertemuan WTO. Sehingga negara berkembang tidak memiliki posisi yang sama dalam perundingan kesepakatan. Hasil kesepakatan WTO dalam Paket Bali menjadi sejarah penting ketika Amerika Serikat mengalah kepada India. Kesepakatan WTO terbentuk setelah Amerika Serikat memperbolehkan India dan negara-negara berkembang lainnya mempertahankan kebijakan subsidi pangannya. Namun di sisi lain, Amerika Serikat melarang India dan negara-negara berkembang memperluas produk pertaniannya ke pasar internasional. Amerika Serikat mengkhwatirkan apabila produk India dan negara-negara berkembang berkembang di pasaran maka akan dapat dapat mengganggu harga komoditas dunia (Berita Satu 2013). Selain itu, India dan negara-negara berkembang juga diwajibkan melaporkan kebijakan subsidi pangan kepada WTO.

Penelitian ini berupaya mengkaji kegelisahan pemerintah India dalam menghadapi globalisasi. Hal ini dikaitkan dengan ancaman keamanan manusia salah satunya kebutuhan akan pangan. Sebagai negara berkembang rawan akan berbagai potensi ancaman. Globalisasi membawa dampak bergeraknya perusahaan multinasional dengan kekuatan politik ekonomi yang besar yang membawa investasi asing langsung yang dibutuhkan oleh negara berkembang untuk menggerakkan roda perekonomiannya. Namun, di balik pengejaran investasi, kelompok masyarakat miskin menjadi taruhannya. Maka, di balik perdagangan bebas yang semakin menguat, negara perlu untuk melakukan intervensi demi kepentingan nasional, salah satunya untuk melindungi kelompok masyarakat miskin. Maka pertanyaan penelitian yaitu bagaimana kebijakan pangan India memperkuat kepentingan nasionalnya di tengah rezim globalisasi, dan bagaimana India menunjukkan power dalam mendorong kesepakatan di forum WTO yang mendukung posisi negara berkembang untuk mempertahankan subsidi terhadap produk pertanian.

\section{Globalisasi}

Terdapat dua pendekatan dalam teori organisasi internasional yaitu pendekatan rezim dan pendekatan kelembagaan. Rezim, mengacu pada dampak tingkah laku organisasi internasional sebagai aktor yang berhadapan dengan negara. Organisasi internasional dapat didefinisikan sebagai seperangkat norma, aturan dan prosedur pengambilan keputusan sebagai aktor yang terlibat dalam beragam isu (Barkin 2006, 27). Paham realis menekankan pada kesadaran akan hubungan kekuatan yang dapat memaksa negara-negara melalui lingkungan yang anarkis dalam upaya bertahan dan menciptakan rintangan dalam kerjasama internasional yang kemudian muncul pertanyaan mengenai 
keefektifan rezim internasional. Neoliberal atau interest-based theories of regimes memiliki pengaruh terhadap pendekatan yang diterapkan lembaga internasional. Neoliberal menekankan peran rezim internasional dalam membantu negara-negara untuk mewujudkan kepentingan-kepentingannya (Hasenclaver et al. 2004, 4).

Barkin (2006) menyatakan globalisasi dapat mengubah kedaulatan internal dan eksternal. Globalisasi dapat mempengaruhi kedaulatan internal karena dikuasainya otonomi negara. Terdapat kekuatan pengambilan keputusan dari pemerintah kepada organisasi internasional dan aktor non negara yang mengakibatkan berkurangnya kemampuan negara dalam dominasi pengambilan keputusan dan kebijakan. Globalisasi dapat mempengaruhi kedaulatan eksternal akibat hilangnya monopoli sistem kedaulatan negara dalam kegiatan politik internasional. Organisasi internasional dapat mempengaruhi otonomi pengambilan keputusan, namun aktor lain seperti NGO dapat berpartisipasi dalam perumusan kebijakan internasional dan memperlemah sistem negara tradisional.

Globalisasi merupakan proses yang tidak dapat diacuhkan, namun bukan pula berbentuk penyeragaman dampak terhadap sebagian masyarakat, kelompok maupun kelas. Dalam konsep hubungan internasional, globalisasi merupakan hubungan antara negara dan masyarakat ditandai dengan interdependensi (saling ketergantungan). Globalisasi ditandai pembentukan ekonomi dan percepatan pertumbuhan ekonomi melalui ekonomi kapitalis yang mengabaikan batas-batas negara dan membentuk ekonomi autarki (mengatur ekonomi secara mandiri). (Viotti \& Kauppi 2006). Namun ekonomi kapitalis menyebabkan konsumerisme, penyebaran modal keuangan juga meningkatkan modal informasi dan komunikasi. Selain itu globalisasi menyebabkan berkembangnya jaringan perusahaan transborder, merger perusahaan besar dan meningkatnya oligopoli global (Scholte 2000, 131).

Proses globalisasi yang sedang berjalan memicu suatu kondisi yang timpang, baik negara maju maupun negara berkembang. Kemakmuran sedang digalakkan, namun masih terlalu banyak negara maupun masyarakat yang tidak ikut merasakannya. Stiglitz (2006) memaparkan lima masalah terkait globalisasi: 1) Aturan main globalisasi tidak adil, dirancang secara khusus untuk menguntungkan negara industri maju. 2) Globalisasi mendahulukan nilai-nilai kebendaan di atas nilai-nilai lain, seperti lingkungan dan kehidupan itu sendiri. 3) Cara pengelolaan globalisasi telah mencabut sebagian besar kedaulatan negara-negara berkembang, termasuk kemampuan membuat keputusan-keputusan di bidang-bidang penting yang mempengaruhi kehidupan masyarakat. 4) Sementara pendukung globalisasi mengklaim bahwa setiap orang akan 
mendapat keuntungan secara ekonomi, terdapat banyak bukti menunjukkan banyak pihak yang dirugikan. 5) Sistem ekonomi yang dipaksakan pada negara-negara berkembang bahkan untuk beberapa kasus terlalu dipaksakan, kurang tepat dan sering kali sangat merusak.

Mengacu pada paparan Stiglitz mengenai aturan main globalisasi yang tidak adil, bahwa rezim perdagangan bebas yang dibentuk oleh WTO seolah menafikan dikotomi antara core (pusat) dan periphery (pinggiran). Dua kutub yang berbeda keadaan ekonominya, ketidakadilan ketika standar perdagangan bebas maupun sistem ekonomi dunia memfasilitasi kepentingan core, sementara periphery dalam kondisi yang yang terus menerus 'merangkak' dan terpaksa mengikuti standar global agar tidak menjadi terasing dalam dunia internasional. Arlene B. Tickner (2013) memaparkan terjadinya ketergantungan dalam interaksi antara struktur lokal, sosial, ekonomi dan politik dengan sistem global. Sehingga elit lokal dan negara menjadi pemain aktif dalam internasionalisasi untuk penalaran kapitalis yang memfasilitasi dominasi kekuatan asing (Cardoso 1977; Cardoso and Faletto 1978). Maka dependensi menjadi hasil dari faktor endemik dari periphery, di mana kelompok elit berada di antara pengejaran perencanaan nasional dan sisi lainnya menjadi aliansi bagi core. Sehingga dependensi memandang core melakukan eksploitasi pada periphery (Tickner 2013, 639).

\section{Keamanan Manusia}

Dalam paper ini dibahas dan dianalisa mengenai pengejaran kepentingan nasional India terkait keamanan pangan. Globalisasi memiliki keterkaitan dengan keamanan manusia. Era globalisasi memunculkan banyak ancaman yang tidak hanya mengancam negara, namun mengancam manusia sebagai individu. Bagaimana masalah global dapat menjadi ancaman bagi keberlangsungan hidup manusia. Globalisasi menampakkan upaya penyamaan dalam berbagai bentuk sistem di dunia, namun permasalahan terjadi bagi negara-negara berkembang dan terbelakang yang 'dipaksa' untuk mengikuti ritme dan standar yang diterapkan oleh negara-negara maju. Maka globalisasi membawa permasalahan karena dipandang belum mampu membawa tatanan dunia yang adil dan belum mampu menolong negara-negara dunia ketiga keluar dari jeratan kemiskinan. Maka, menggunakan dasar keamanan manusia memberikan peringatan dan hirauan bagi negara untuk merumuskan kebijakannya untuk pencapaian kepentingan nasional dan meminimkan dampak negatif bagi warga negaranya dalam pengejaran kepentingan nasional. Pengejaran kepentingan nasional India di tengah berkuasanya rezim internasional dalam menentukan kebijakan terkait keamanan pangan. 
Maka dikaitkan dengan studi hubungan internasional mengenai studi keamanan non tradisional. Isu keamanan non-tradisional di luar hirauan tradisional kajian keamanan. The Copenhagen School mencoba memperluas obyek rujukan isu keamanan dengan tidak lagi berbicara melulu keamanan "negara", tetapi juga menyangkut keamanan "manusia". Hingga saat ini, belum ada kesepakatan bagaimana konsep keamanan manusia harus dipahami dan bagaimana pula aplikasi konsep tersebut di dalam politik praktis (Hadiwinata 2007). Pendekatan nontradisional dengan fokus misalnya pada keamanan ekonomi dan perdagangan, lingkungan, energi, budaya, dan masalah-masalah sosial lainnya. Dengan asumsi-asumsi sebagai berikut : 1) Keamanan seluruh entitas politik di bawah negara. 2) Negara menghadapi tekanan dari lingkungan domestik dan lingkungan internasional. 3) Negara menyerahkan kedaulatannya kepada entitas internasional. 4) Keamanannya bersifat multidimensional dan kompleks tidak hanya bersifat ancaman militer. 5) Negara dan kedaulatannya tidak cukup untuk menjelaskan kompleksitas masalah keamanan. 6) Negara dapat menjadi sumber ancaman keamanan warga negara (Perwita dan Yani 2005, 128).

Menurut Buzan (1991), keamanan menekankan pada nasib manusia, mengenai pengejaran kebebasan dari ancaman. Mengenai cara bertahan, tetapi juga termasuk kondisi yang mendukung keamanan. Keamanan menyentuh nasib sekelompok manusia dan menyentuh keamanan personal menyangkut kehidupan manusia secara individual. Keamanan sekelompok manusia tergantung lima faktor yaitu: Pertama, keamanan militer terpusat pada dua kubu yang saling mempengaruhi dalam gencetan senjata negara-negara yang bertikai baik secara ofensif maupun defensif. Kedua, keamanan politik mengenai stabilitas organisasi suatu negara, sistem pemerintahan dan ideologi yang memberikan legitimasi. Ketiga, keamanan ekonomi menyangkut jalan masuk sumber daya, keuangan, dan pasar yang penting untuk menjaga tingkat kemakmuran dan kekuatan negara. Keempat, keamanan masyarakat yang berkelanjutan dengan kondisi evolusi dari pola tradisional seperti bahasa, kebudayaan, dan agama juga identitas dan kebiasaan nasional. Kelima, keamanan lingkungan hidup menyangkut pemeliharaan lokal dan biosfir planet sebagai sistem yang memiliki dukungan penting dimana hidup manusia tergantung.

Keamanan manusia dengan fokus perhatian pada keamanan umat manusia berfokus pada keamanan nasional. Atau secara meluas ditafsirkan sebagai human security issue menjadi fokus individu dimana mereka tinggal dengan pertentangan pandangan bahwa mereka merupakan bagian warga suatu negara (Viotti \& Kauppi 2006, 432). Beberapa area yang teridentifikasi dalam konsep keamanan manusia yang dirumuskan UN Development Programme dalam laporannya 
"Human Development Report" tahun 1994 memuat poin-poin : Pertama, keamanan ekonomi: Dalam hal ini adanya jaminan atas akses pada pekerjaan yang layak, juga terbebas dari hal-hal yang mengancam keberlangsungan ekonomi seperti pengangguran, kenaikan harga, krisis ekonomi, kemiskinan. Kedua, keamanan pangan yakni memiliki akses terhadap bahan pangan, juga terbebas dari ancaman-ancaman yang mempengaruhi akses terhadap pangan seperti kondisi lingkungan, distribusi bahan pangan. Ketiga, keamanan kesehatan yakni memiliki akses terhadap perawatan kesehatan seperti akses dan ketersediaan fasilitas kesehatan (adanya rumah sakit, obat-obatan) dan perlindungan dari hal-hal yang mengancam kesehatan seperti epidemi penyakit, kondisi lingkungan. Keempat, keamanan lingkungan : dalam hal ini adanya perlindungan dari dampak-dampak negatif yang ditimbulkan degradasi lingkungan. Kelima, keamanan personal yakni terbebas dari ancaman yang ditimbulkan oleh negara-negara, kelompok-kelompok tertentu atau sesama individual seperti rasionalisme, diskriminasi, eksploitasi, kejahatan dan lain-lain. Keenam, keamanan masyarakat yakni terbebas dari praktek-praktek negatif atau berbahaya di masyarakat. Ketujuh, keamanan politik yakni dapat menikmati hak-hak asasi manusia dan terlepas dari tekanan politik.

Definisi keamanan pangan menurut FAO (Food and Agricultural Organization) yaitu keamanan pangan untuk tingkat individu, rumah tangga, nasional regional dan global dapat diraih ketika semua orang, pada saat bersamaan, memiliki akses yang cukup secara fisik dan ekonomi, dengan makanan yang aman dan bernutrisi sesuai dengan kebutuhan dan pilihan pangan untuk gaya hidup yang aktif dan sehat (Schanbacher 2010, 13). Keamanan pangan berimplikasi sangat penting bagi keamanan manusia. Keamanan pangan menjadi isu penting bagi negara-negara berkembang untuk mendukung kualitas manusia untuk menunjang pembangunan.

\section{Upaya WTO dalam Liberalisasi Pertanian}

Rezim perdagangan lahir di tengah konflik antara juru runding Amerika Serikat dan Inggris di Bretton Woods. Kesepakatan kompromi InggrisAS akhirnya menciptakan Organisasi Perdagangan Internasional (International Trade Organization-ITO) yang membuat isu-isu perdagangan tetap tak terpecahkan. Maka tindakan penengahnya di tahun 1948 Amerika Serikat menciptakan GATT (General Agreement on Tariffs and Trade). (Gilpin 2002, 56). Setelah melalui berbagai putaran, Putaran Uruguay merupakan sebuah tahapan negosisasi perdagangan yang ditandatangi di Marrakech pada 15 April 1994. GATT beranggotakan 128 negara yang kemudian berganti nama menjadi WTO (World Trade Organization). Berdirinya World Trade Organization 
(WTO) pada 1 Januari 1995, menjadi titik yang menandai suatu wujud formalisasi dan institusionalisasi perdagangan bebas dunia. Putaran Uruguay yang melahirkan WTO merupakan sebuah fase baru sejarah perdagangan dunia di dalam sebuah era baru globalisasi neoliberal (Mantra 2011, 42).

Berbagai kesepakatan baru yang dicapai dalam Putaran Uruguay sebagian besar membawa dampak kerugian bagi perekonomian negaranegara berkembang terutama dengan diterapkan penghapusan subsidi ekspor produk-produk yang justru menjadi andalan dari negara-negara berkembang. Jejak sejarah terbentuknya WTO melalui Putaran Uruguay, tidak dapat dilepaskan dari kepentingan domestik dan internasional perdagangan Amerika Serikat. Putaran Uruguay yang melahirkan WTO tidak dapat dilepaskan dari persoalan defisit perdagangan yang dialami Amerika Serikat pada tahun 1980-an (Mantra 2011, 43). Perjanjian perdagangan Putaran Uruguay menimbulkan masalah seperti perjanjian tersebut tidak adil karena negara miskin semakin terpuruk, Putaran Uruguay membuat aturan permainan yang tidak adil menjadi semakin tidak adil. Negara-negara maju menetapkan tarif lebih tinggi pada negara-negara berkembang daripada negara maju (Stiglitz 2006, 142). Namun putaran Uruguay mencapai sejumlah keberhasilan penting dalam sektor pertanian: penyertaan perdagangan pertanian dalam kerangka kerja WTO.

Pada November 2001, para menteri perdagangan anggota WTO mengadakan pertemuan di Doha, Qatar. Negosiasi mengalami penolakan negara-negara maju untuk memotong subsidi di bidang pertanian. Stiglitz (2006) menunjukkan bahwa Amerika Serikat mengeluarkan rencana baru di bidang pertanian yang menyatakan akan menambah subsidi tersebut hampir dua kali lipat. Putaran Doha gagal mencapai kesapakatan. Negosiasi WTO dipenuhi dengan beragam perundingan mengenai subsidi pertanian yang diawali pada Juli 2006. Hal tersebut mengikuti pertemuan pada menteri Uni Eropa tahun 2008 menghasilkan ketidaksepakatan

antara ekspor komoditas pertanian dan kesepakatan terkait 'special safeguard measure' untuk melindungi petani dari dampak kebijakan impor.

Pada pertemuan General Council WTO di Jenewa pada 26 November 2013 (pertemuan sebelum pertemuan puncak di Bali) gagal menghasilkan kesepakatan. Maka Paket Bali dianggap berhasil karena kesepakatan mengenai tiga agenda yaitu trade facility, kesepakatan sektor pertanian dan pembangunan negara-negara kurang berkembang. Kesepakatan trade facility memberi ruang bagi negara-negara berkembang dan kurang berkembang untuk memperluas pasar dan mendorong ekspornya ke negara-negara maju. Kesepakatan sektor 
pertanian, Paket Bali memberikan keleluasaan bagi negara-negara berkembang, khususnya negara dengan populasi besar seperti India untuk memberikan subsidi kepada petaninya dan menjamin ketersediaan pangan bagi warga miskin. Maka negara-negara berkembang tidak diwajibkan mengacu pada pengaturan besaran harga acuan pokok produk pertanian sesuai dengan Agreement on Agriculture (AoA) 1994 hasil kesepakatan Putaran Uruguay mengenai mekanisme pemberian subsidi pertanian bagi negara maju dan negara berkembang.

\section{Gejolak atas Keputusan WTO di India}

Sejak memperoleh kemerdekaan, India telah menetapkan open economy. Narayanan (2009) menjelaskan setelah penerapan reformasi ekonomi tahun 1991, India menjadi tujuan utama investasi retail global, operasi perusahaan multinasional, terserapnya investasi asing langsung yang masuk dan menguasai pasar India (Andersen \& Cheng 2009, 23). Selain itu, India aktif dalam forum multilateral internasional yaitu pertemuan WTO dan Forum Ekonomi Dunia. Namun pada tahun 1999 dan tahun 2000, Delegasi India meninggalkan Pertemuan WTO di Seattle, dimana AS dan Uni Eropa menentukan standar hak-hak buruh dan standar lingkungan hidup sebagaimana investasi dan kompetisi multilateral. Dalam kedua forum tersebut, India memimpin negaranegara berkembang untuk mempertahankan permintaan liberalisasi perdagangan. Menteri Perdagangan dan Industri, Murasoli Maran menawarkan diri untuk memimpin negara-negara berkembang dalam proses negosiasi, termasuk negara- negara maju yang menyetujui reformasi WTO dan upaya menghapus "isu non perdagangan". India adalah pemain ekonomi penting dan kemunculannya menjadi salah satu negara super power (Alamgir 2009, 26).

Bergabungnya India ke dalam WTO pada 1 Januari 1995 menimbulkan dampak negatif. Hal tersebut akibat kebijakan WTO yang mengatur perdagangan dan ketetapan terkait subsidi pertanian. Kelompok petani di India umumnya menganggap WTO sebagai musuh yang berperan salah dalam globalisasi. Harga beberapa hasil panen mengalami penurunan drastis setelah pemerintah memberlakukan sejumlah pembatasan sebagai dampak bergabungnya India dengan WTO. Tergabungnya India ke dalam WTO membawa konsekuensi yaitu pemerintah India harus mengurangi hambatan perdagangan. Pada tahun 2001, harga kapas maupun harga pangan di India mengalami penurunan drastis. India mengurangi hambatan tarif dan non tarif untuk impor material untuk produk ekspor. India pun menyetujui aturan intellectual property WTO. Petani diharuskan menjual bibitnya ke perusahaan multinasional seperti Monsanto setiap tahunnya. Monsanto beroperasi di India tahun 1995 setelah kesepakatan pasca 
WTO. Monsanto merupakan perusahaan multinasional modifikasi bibit genetik produk pertanian. Namun bergabungnya petani ke Monsanto menyebabkan pengaruh negatif yaitu menurunya penghasilan petani di India. Sebuah insiden tragis tahun 1985, sebanyak 500 petani katun di Warangal distrik Andhra Pradesh berupaya bunuh diri dengan meminum pestisida dan insektisida (Alamgir 2009, 34).

Sejumlah tindakan protes diberlakukan yaitu tahun 1998, terdapat gerakan menuntut penutupan Monsanto (Monsanto melakukan monopoli budidaya kapas dan jagung) dengan slogan protes "Monsanto, Quit India". Kemudian Juni 1999, ratusan petani India terbang ke Jenewa memprotes kebijakan WTO di bidang pertanian. Aksi protes pun kembali terjadi pada Oktober 2001, Forum petani India (Indian Kisan Sabha) melakukan kecaman terhadap WTO dan Aktivis lingkungan hidup India mengecam operasi Coca Cola, Pepsico dan Monsanto untuk keluar dari India. Pada Oktober 2005, sebanyak 50.000 petani dari empat belas negara bagian India melakukan protes terhadap WTO di Mumbai. Hal tersebut terkait dengan peningkatan produk pangan impor di India dan penarikan sejumlah subsidi pertanian. Meningkatnya perdagangan dan kehadiran perusahaan multinasional juga mempersatukan kelompok pegiat lingkungan hidup di kota dan pedesaan India. Solidaritas tersebut melakukan penolakan dan tuntutan kepada pemerintah untuk menarik perusahaan Coca Cola, pepsico dan Monsanto sebagai bagian agen globalisasi (Alamgir 2009, $35)$.

Pada 3 September 2010, terjadi aksi protes yang dihadiri 50.000 ribu orang dari Komite Koordinasi Gerakan Petani India terhadap WTO di New Delhi. Protes tersebut dilakukan jelang pertemuan WTO pada putaran Doha. Para petani berjalan membawa poster yang menegaskan WTO harus keluar dari pertanian. Petani-petani yang datang dari negara bagian Uttar Pradesh, Punjab, Haryana, Madhya Pradesh, Himachal Pradesh, Rajasthan, Maharashtra, Uttranchal and Karnataka. Dalam aksi protes tersebut perwakilan petani bertemu dengan Menteri Perdagangan Anand Sharma. Kemudian aksi protes lain terjadi pada 18 Oktober 2012, ratusan petani India yang tergabung dalam BKU (Bharatiya Kisan Union) melakukan aksi menolak jagung GMO (Genetically Modified Organic-rekayasa genetik) yang merupakan produk Monsanto. Ratusan petani menuntut Monsanto keluar dari India. Koalisi India bertemu dengan Menteri Pertanian Paramvir Singh untuk menunjukkan penolakan terhadap GMO. Aksi petani India mengikuti rekomendasi yang dikeluarkan oleh Mahkamah Agung India. Rekomendasi ini mengharuskan moratorium selama 10 tahun pada semua uji coba tanaman GMO di India. Perlawanan publik India terhadap GMO semakin meluas semenjak semakin banyak bukti-bukti 
ilmiah yang berkembang dan menunjukkan dampak negatif GMO pada kesehatan manusia dan lingkungan.

\section{Kebijakan Keamanan Pangan India}

Sebelum pertengahan 1960-an India mengandalkan impor dan bantuan pangan untuk memenuhi kebutuhan pangan dalam negeri. Pada tahun 1965 dan 1966, India mengalami kekeringan. Maka pemerintah India saat itu, memulai melakukan reformasi kebijakan pertanian dan bahwa India tidak dapat bergantung pada bantuan asing untuk memenuhi kebutuhan pangan di dalam negeri. India mengadopsi reformasi kebijakan yang difokuskan pada tujuan swasembada gandum yang merupakan bahan makanan pokok selain beras. India tidak hanya mengalami tantangan cuaca, India pun mengalami pertumbuhan penduduk yang cukup cepat. Jumlah populasi India menempati urutan kedua di dunia. Maka Permasalahan penduduk pun menjalar ke permasalahan lainnya. Salah satunya adalah penyediaan pangan yang memadai bagi seluruh penduduk India.

Selain itu, krisis harga pangan pun menjadi sorotan bagi pembuat kebijakan di India. Dalam Putaran WTO di Doha, India mengajukan usulan mengenai keamanan pangan di negara-negara berkembang. India memandang permasalahan pangan akan menjadi perhatian global dan diperlukan langkah-langkah nyata untuk menghadapi kerawanan pangan. India memandang fluktuasi harga pangan menjadi hal yang serius maka diperlukan penerapan subsidi produk pertanian dan pangan untuk negara-negara berkembang.

Dalam penelitian Ganguly dan Gulati (2013) disebutkan bahwa India mengalami krisis harga pangan global tahun 2007-2008, kemudian India mengambil kebijakan ekspor untuk beberapa komoditas pangan (melarang ekspor untuk komoditas gandum dan beras) dan tidak mengizinkan harga pupuk domestik mengalami peningkatan sesuai harga global (terutama urea). Pertengahan tahun 2009, kenaikan harga pangan dimulai dengan meningkatnya kekeringan yang terjadi di India. Walaupun pertumbuhan ekonomi India mengalami peningkatan, namun India mengalami permasalahan kemiskinan. Sebanyak 41,6\% penduduk India atau 456 juta jiwa hidup dengan upah di bawah 1,25 dolar per hari. Kebijakan tersebut sejalan dengan arsitek ekonomi India yang juga menjabat menjadi Perdana Menteri India, Manmohan Singh (Ganguly \& Gulati 2013, 1).

Pada awal tahun 2009, Manmohan Singh terpilih kembali menjadi Perdana Menteri India mengikuti kesuksesan pemilu sebelumnya termasuk keberhasilannya melindungi India dari krisis pangan dunia. 
Harga beras dunia meningkat hingga 16\% antara Juni 2007 dan Juni 2008, namun kenaikan harga pangan yang terjadi hanya mencapai $7,9 \%$ (Gouel 2013, 2). Untuk melindungi keberadaan padi-padian maupun biji-bijian, maka pada Oktober 2007 India melarang ekspor beras nonBasmati. Larangan tersebut mengakibatkan harga beras di India lebih stabil. India telah memberlakukan kebijakan pangan yang yang didukung dengan keamanan pangan dalam upaya antisipasi melonjaknya penduduk.

India berupaya memenuhi kebutuhan dalam negeri dalam produksi bahan baku seperti beras dan gandum. Negara memainkan peran penting dalam kebijakan pertanian berdasarkan konstitusi India. Pada tahun 2009, pemerintah India telah mengeluarkan rancangan UndangUndang keamanan pangan nasional dengan harapan apabila terjadi inflasi tidak mempengaruhi harga pangan (Gouel 2013, 22).

Pada tahun 2013, upaya progresif pemerintah India untuk keamanan pangan sangat terasa. Pada 26 Agustus 2013, pemerintah India meluncurkan subsidi pangan dengan perkiraan nilai 19,8 miliar dolar per tahun. Program kebijakan ini merupakan program pangan terbesar dunia. Walaupun politik domestik India gaduh menyatakan kebijakan ini sebagai upaya populer jelang Pemilu pada Mei 2014. Pada 2 September 2013, parlemen India menyepakati anggaran sebesar 20 miliar dolar untuk memberikan makan bagi 800 juta orang yang hidup di bawah garis kemiskinan dari total 1,2 miliar rakyat India. Pada 12 September 2013, pemerintah India mengesahkan The Indian National Food Security Act yang bertujuan melakukan subsidi pangan untuk memenuhi kebutuhan 1,2 ribu juta jiwa di India. Beberapa produk pangan yang mendapatkan subsidi diantaranya beras dan gandum. Sebelumnya Undang-Undang keamanan pangan telah memasuki proses pembahasan berupa Rancangan Undang-Undang Keamanan Pangan India pada tahun 2009. Namun upaya percepatan pengesahan Rancangan Undang-Undang Keamanan Pangan marathon dilakukan pada tahun 2012. Undang- Undang Keamanan Pangan mengatur harga jual bahan makanan pokok, terutama subsidi bahan pangan untuk warga miskin India.

India menjalankan Undang-Undang Keamanan Pangan dengan persediaan pangan di pasar untuk menyeimbangkan kenaikan harga. Perkiraan anggaran mencapai 18 milyar dollar. Undang-Undang Keamanan Pangan menegaskan sebanyak 75 persen populasi India di pedesaan dan 50 persen mendapatkan 5 kilogram biji-bijian per bulan dengan subsidi sebesar 3 rupee ( 5 sen dolar) untuk beras dan 2 rupee per kilogram untuk gandum. Tujuannya agar mencegah India dari kelaparan dan kekurangan gizi. India menemati urutan ke-65 dari 79 
peringkat Global Hunger Index. Undang-Undang Keamanan Pangan India memiliki dua tujuan yaitu mempermudah akses pangan dan endukung petani dalam negeri. Sebanyak 22 milyar dollar untuk skema kesejahteraan untuk subsidi gandum dan beras sebesar 67\% untuk 1,2 milyar penduduk. Skema ini akan diperluas secara massif untuk memperkuat program penyediaan pangan untuk 218 juta penduduk (CNN 2013).

\section{Telaah Kebijakan Keamanan Pangan India}

Di tengah berkuasanya rezim globalisasi, India mampu menampakkan kehadiran negara sebagai aktor utama dalam penentuan kebijakan dalam negeri. Globalisasi mampu membuat negara seakan 'tidak berdaulat' dalam penentuan kebijakan dalam negeri sehingga mengikuti agenda global. Rezim internasional telah merumuskan kebijakan yang 'seolah' mencapai konsensus, namun menjadi pilihan yang pahit dan tidak ada pilihan lain yang lebih baik yang diterima oleh negara-negara berkembang. Negara berkembang tengah mengalami pergulatan ekonomi dalam menerima kenyataan standarisasi perdagangan yang ditetapkan oleh WTO dengan dalih menciptakan perdagangan global yang lebih adil. Standarisasi tersebut berupa penetapan harga, pengurangan subsidi, penghilangan hambatan perdagangan hingga melucuti negara-negara berkembang agar tidak memberikan proteksi perdagangan. Maka ketika forum pertemuan WTO dilakukan, sangat jarang negara berkembang mampu menyuarakan aspirasinya di forum tersebut. India nampaknya fokus untuk memperjuangkan kepentingan nasionalnya dalam bidang pertanian. Pada Putaran Doha WTO, India memberikan usulan mengenai besaran subsidi untuk pertanian. Pada pertemuan WTO di Bali, artikulasi kepentingan India terkait subsidi pangan sangat nyata.

India sebagai negara dengan populasi penduduk yang tinggi tentu memiliki persepsi ancaman. Salah satu persepsi ancamannya adalah keamanan pangan. Di tengah ancaman perubahan iklim yang dapat berpengaruh terhadap hasil panen pertanian, sejumlah ancaman mengintai keamanan pangan nampak nyata yaitu liberalisasi perdagangan akan mendorong produk pangan impor yang akan masuk ke India, maka potensi ancaman adalah terjadi ketidakstabilan harga. Selain itu, apabila pemerintah tidak memberikan subsidi pangan, maka akan berpengaruh terhadap daya beli pangan. Apabila harga pangan meningkat maka warga miskin tidak dapat menjangkau pangan maka ancaman kelaparan pun menjadi sangat fatal. Selain itu, terkait dengan keamanan pangan erat kaitannya dengan pertanian. Subsidi pertanian pun diberikan kepada petani agar petani mampu menjaga ketahanan pangan untuk memenuhi kebutuhan pangan di dalam negeri. 
Maitra dan Zainulbhai (2013) mencatat India saat ini memiliki sekitar 70 persen penduduk India tinggal di pedesaan. Tinggal di pedesaan menghadapi kenyataan yaitu terbelit dalam kemiskinan. Sebanyak 300 juta penduduk desa India hidup di bawah garis kemiskinan; tingkat membaca hanya $46 \%$ dan hanya satu dari lima keluarga yang memiliki akses untuk sanitasi dasar. Selain itu, sebanyak dua pertiga penduduk India (sekitar 833 juta orang) hidup di pedesaan. Sektor pertanian menyumbang 14\% untuk PDB (Produk Domestik Bruto). India telah mencapai swasembada dalam pangan biji-bijian (beras dan gandum) sejak pertengahan 1990-an, dengan produksi yang meningkat dari 130 juta ton pada tahun 1980 menjadi 240 juta ton pada tahun 2010. Saat ini India merupakan produser pertanian ketiga di dunia, setelah China dan Amerika Serikat, dengan pemasukan sekitar 260 milyar dollar per tahun (McKinsey 2013, 247).

Berdasarkan persentasi pertanian untuk PDB, subsidi pangan mengalami peningkatan dari 1,8 persen menjadi 5,8 persen selama tahun 1991-1992 dan 2010-2011. Subsidi pangan, meningkat berbanding dengan pertumbuhan ekonomi setiap tahun rata-rata mencapai 17,8 persen selama tahun 1990-an, yang kemudian cukup stabil antara tahun 2002-2003 dan 2006-2007 karena komoditas pangan biji-bijian mengalami kenaikan harga yang cukup rendah (Sharma 2012, 2). Pemerintah India menjadikan subsidi sebagai instrumen bagi kebijakan domestik. Kebijakan subsidi cenderung populer bagi masyarakat, namun untuk subsidi pangan menjadi hal yang sangat strategis guna menahan angka kemiskinan yang cukup tinggi di India.

India mampu merumuskan kepentingan nasional dalam hal keamanan pangan. Kehadiran Undang-Undang Keamanan Pangan menjadi dasar kebijakan dalam pengejaran kepentingan nasional India. Menghadapi 'ancaman' globalisasi, India mampu membangun fondasi untuk menahan ancaman tersebut. Walaupun penetapan kebijakan terkait dengan politik domestik yang digunakan dapat menguntungkan untuk kepentingan politik domestik tertentu, namun kebijakan keamanan pangan ini merupakan kebijakan jangka panjang dalam upaya melindungi keamanan manusia bagi warga negara India. Selain merumuskan kebijakan, India pun mampu memperjuangkan kepentingan nasionalnya dalam forum internasional. India dengan percaya diri mampu memperjuangkan kepentingan nasionalnya dan bersikap tegas dengan menolak kesepakatan sepihak yang diajukan oleh negara-negara maju. Walaupun India tidak melakukan aliansi dengan negara lain dalam penolakan draft yang diajukan WTO, namun India mampu menekan negara-negara maju agar menurunkan 'egoismenya' untuk menyetujui kebijakan mengenai kesepakatan besaran subsidi pertanian. Kebijakan nasional yang jelas dan terarah menjadikan artikulasi kepentingan yang disuarakan delegasi India di WTO memiliki 
dasar yang kuat dan terukur. Dalam beberapa hal, India dianggap konsisten menyuarakan kepentingan nasionalnya ketika menghadapi WTO. Bahkan tindakan India diikuti oleh beberapa negara berkembang lainnya yang menyuarakan hal yang sama.

Bersandar pada pemahaman dependensi, rezim globalisasi dengan jelas membagi power negara-negara yang tergabung dalam core maupun periphery. India telah mempersiapkan diri untuk membentengi ancaman globalisasi ekonomi. Globalisasi menimbulkan garis kedaulatan yang semakin samar. India memilih untuk mempertahankan kedaulatannya dalam hal pangan. Selain untuk melindungi mayoritas masyarakat India yang bersandar pada sektor pertanian sehingga fluktuasi harga dapat ditekan karena produk lokal dengan daya beli yang disesuaikan dengan mayoritas masyarakat India. Selain itu, rezim globalisasi ekonomi menuntut pengurangan subsidi hingga penghapusan subsidi bagi pertanian. India mampu untuk tidak berkompromi mengenai besaran subsidi. Subsidi menjadi perhatian bagi pemegang kebijakan untuk melindungi komoditas yang menjadi kebutuhan pokok.

\section{Simpulan}

Pertemuan WTO di Bali menorehkan sejarah dengan adanya ketetapan mengenai kenaikan besaran subsidi pangan sebesar $15 \%$. India menorehkan sejarah dalam perundingan WTO karena bersikap tegas dengan menolak usulan dari negara-negara maju. Sebagai negara berkembang, India mampu memberikan pengaruh dengan bergabungnya beberapa negara berkembang lainnya yang mendukung usulan India dalam forum WTO. Walaupun tuntutan India berhasil dijadikan kesepakatan, namun sejumlah konsekuensinya pun ada seperti pembatasan perdagangan produk India. Kesepakatan WTO mampu bersanding dengan kebijakan dalam negeri India yang baru digulirkan bersamaan dengan disahkannya Undang-Undang Keamanan Pangan tahun 2013. India bercermin dari sejumlah dampak negatif yang menimpanya terkait keanggotaannya di WTO. Warga miskin yang paling dirugikan akibat kebijakan WTO yang diterapkan di India. Maka India pun bangkit dengan mengatur strategi melawan WTO dengan posisi tawar keamanan pangan yang menjadi salah satu hirauan WTO.

Globalisasi menjadi ancaman terhadap kedaulatan negara akibat keanggotaan satu negara dalam forum multilateral yang mewajibkan negara untuk tunduk pada aturan main rezim internasional. Globalisasi belum memperlihatkan sisi positif bagi negara dunia ketiga karena aturan main yang menguntungkan pihak negara-negara maju. Arus perdagangan bebas menimbulkan konsekuensi kepemilikan sumber 
daya alam oleh perusahaan multinasional sebagai bentuk investasi asing langsung. Maka, apabila tidak ada intervensi dari pemerintah dapat dipastikan kedaulatan pangan akan terancam. Selain itu, opsi mudah terkait penerapan impor pangan tidak menjadi pilihan bagi pemerintah India. Selain memastikan kebutuhan pangan, pemerintah India juga berkepentingan melindungi produk pertanian dalam negeri. Produk pangan domestik menjadi tumpuan bagi pemenuhan kebutuhan pangan dalam negeri. India lebih memilih untuk membuat regulasi untuk memperkuat kedaulatan pangan dan pemberian subsidi terhadap produk pangan. Walaupun, India masih menjadi daya tarik untuk penanaman investasi asing bahkan pusat retail pangan dunia sebagai bagian konsekuensi globalisasi ekonomi. Namun, kebijakan pangan India cukup untuk mengakomodir keamanan manusia.

\section{Daftar Pustaka}

\section{Buku}

Alamgir, Jalal. 2009. India `s Open Economy Policy. Globalism, Rivalry, Continuity. New York: Routledge.

Banyu Perwita, Anak Agung ; Yanyan Mochamad Yani. 2005. Pengantar Ilmu Hubungan Internasional. Bandung: Rosda.

Barkin, Samuel J. 2006. International Organization Theories and Institutions. New York: Palgrave Macmillan.

Barnik C. Maitra and Adil Zainulbhai. 2013. India `Farms: Harvesting the Future, dalam Reimagining India. Unlocking The Potential Of Asia `s Next Superpower. McKinsey \&Company. (edited by). New York: McKinsey \& Company. New York.

Buzan, Barry. 1991. People, States and Fear an Agenda for International Security Studies in the Post-Cold War Era. London : Harvester Wheat Sheaf.

Hasenclever, Andreas; Peter Mayer, Volker Rittberger. 2004. Theories of International Regimes. New York : Cambridge University Press.

Hermawan, Yulius P (editor). 2007. Transformasi Isu dan Aktor di dalam Studi Hubungan Internasional : Dari Realisme hingga Konstruktivisme. Dalam Transformasi dalam Studi Hubungan Internasional. Aktor, Isu dan Metodologi. Yogyakarta: Graha Ilmu.

Gilpin, Robert and Jean Millis Gilpin. 2002. Tantangan Kapitalisme Global Ekonomi Dunia Abad ke-21. Jakarta: Murai Kencana.

Mantra, Dodi. 2011. Hegemoni dan Diskursus Neoliberalisme. Menelusuri Langkah Indonesia Menuju Masyarakat Ekonomi ASEAN 2015. Bekasi: Mantra Press.

Schanbacher, William D. 2010. The Politics of Food. The Global Conflict Between Food Security and Food Sovereignity. Santa Barbara: Praeger. 
Scholte, Jan Aart. 2000. Globalization a Critical Introduction. New York : St. Martin`s Press.

Stiglitz, Joseph. 2006. Making Globalization Work. Menyiasati Globalisasi Menuju Dunia Yang Lebih Adil. Bandung : Mizan.

Sudha Narayanan. 2009. A Revolution in the Making: The Case of AgroFood Retailing in India, dalam Andersen, Pinstrup Per \& Fuzhi Cheng (editors). Case Studies In Food Policy For Developing Countries. Volume II. Domestic Policies For Markets, Production, and Environment. New York: Cornell University Press.

UN Development Programme. 1994. Human Development Report. New York : Oxford University Press.

Viotti, Paul R; Mark V. Kauppi. 2006. International Relations and World Politics Security, Economic, Identity. Third Edition. New Jersey: Prentice Hall.

\section{Jurnal}

Tickner, Arlene B. 2013. Core, Periphery and (neo) imperialist International Relations. European Journal of International Relations. Sage Publication. 5 September 2013. http://ejt.sagepub.com/content/19/3/627.full.pdf+html (Diakses 12 Mei 2015)

\section{Working Paper}

Ganguly, Kavery dan Ashok Gulati. 2013. "The Political Economy of Food Price Policy. The Case of India”. [online] NU (United Nations University) WIDER Working Paper No. 2013/2014. Dalam http://www.wider.unu.edu/publications/workingpapers/2013/en_GB/wp2013-034/ (Diakses 9 Maret 2014)

Gouel, Christophe. 2013. "Food Price Volatility and Domestic Stabilization Policies in Developing Countries". [online] Dalam http://www.nber.org/papers/w18934 (Diakses 9 Maret 2014)

Sharma, Vijay Paul. 2012. "Food Subsidy in India: Trends, Causes and Policy Reform Options". [online] Indian Institute of Management Ahmedabad. Dalam http://www.iimahd.ernet.in/assets/snippets/ workingpaperpdf/5337679172012-08-02.pdf (Diakses12 Mei 2015)

\section{Media Massa Online}

Antara. 2013. Empat Negara Tolak Draft Paket Bali. [online] http://www.antaranews.com/berita/408421/empat-negara-tolakdraft-paket-bali. Diakses 18 Februari 2014.

Asian Human Right Commission. 2010. India`s National Food Security Act: Entitlement of Hunger. [online] 
http://www.humanrights.asia/resources/journalsmagazines/eia/eiav4n2/indias-national-food-security-actentitlement-of-hunger. Diakses 9 Maret 2014

BBC Indonesia. 2013. RUU Pangan Kontroversial di India Disetujui. [online] http://www.bbc.co.uk/indonesia/dunia/ 2013/o9/130903_india_kebijakan_pangan.shtml. Diakses 18 Februari 2014.

Berita Satu.com. 2013. Berkat India, Negara Berkembang Bisa Mempertahankan Subsidi Pangan. [online] http://www.beritasatu.com/ekonomi/154493-berkat-india-negaraberkembang-bisa-mempertahankan-subsidi-pangan.html. Diakses 18 Februari 2014.

Detik. 2013. Pertanian India Versus Indonesia. [online] http://news.detik.com/read/2013/o8/30/113726/2345087/471/2/ pertanian-india-versus-indonesia . Diakses 9 Maret 2014.

India (G-33) Proposal on Food Security: A wrong move can jeopardize India's food security forever. [online] http://focusweb.org/content/india-g-33-proposal-food-securitywrong-move-can-jeopardize-india\%E2\%80\%99s-food-securityforever\#sthash.UUBueZrF.dpuf . Diakses 9 Maret 2014.

Indopos. 2013. India Paling Keras Menolak Paket Bali. http://www.indopos.co.id/2013/12/india-paling-keras-menolakpaket-bali.html\#.UvjIhc7--rw . Diakses 18 Februari 2014.

Joshua Meltzer. 2014. OPINION. Improving Indian Food Security: Why Prime Minister Modi Should Embrace the WTO. [online] http://www.brookings.edu/research/opinions/2014/o5/16-worldtrade-organization-india-food-security-meltzer

Kompas. 2013. Negara Maju Optimistis Pertemuan WTO di Bali Capai Kesepakatan.[online]

http://bisniskeuangan.kompas.com/read/2013/12/05/1538196/Ne gara.Maju.Optimistis.Pertemuan.WTO.di.Bali.Capai.Kesepakatan . Diakses 18 Februari 2014.

Kontan. 2013. India Luncurkan Kebijakan Pangan Terbesar Dunia! http://internasional.kontan.co.id/news/india-luncurkan-kebijakanpangan-terbesar-dunia . Diakses 18 Februari 2014.

Sindo. 2013. Kebijakan Pangan Kontroversial -Pemerintah India Putuskan Harga Beras Rp 505 per Kg. [online] http://www.koransindo.com/node/327443 . Diakses 18 Februari 2014.

The Indian National Food Security Act No 20 of 2013.[online] http://indiacode.nic.in/acts-in-pdf/202013.pdf. Diakses 12 Mei 2015.

VOA Indonesia. 2013. India Tolak Pasal Subsidi Pangan Dalam KTT WTO. [online] http://www.voaindonesia.com/content/india-tolakpasal-subsidi-pangan-dalam-ktt-wto/1803163.html. Diakses 18 Februari 2014. 